\title{
POTENTIAL AND OPPORTUNITIES FOR GROW THE SPRING NAKED OATS VARIETY "MINA" (AVENA NUDA, L.) IN THE CONDITIONS OF ORGANIC FARMING IN SAKAR AGRO REGION
}

\author{
Violeta Vateva, Krasimir Trendafilov \\ Faculty of Technics and Technologies of Yambol, \\ Trakia University of Stara Zagora, Bulgaria \\ Graf Ignatiev 38, 8600 Yambol, Bulgaria \\ email: vili13@gmail.com; trendafdilov@outlook.com
}

\begin{abstract}
From all cereals the oats is the culture that due to dietary and healthy impact on the human body becomes more sought after in the market. The residual products of oats after harvesting the grain such as straw and chaff are sought after for animal feed.

The aim of this research is to test the potential opportunities of the spring naked oats variety "Mina", Bulgarian selection, grown on the principles of organic farming. The research is carried out in real ecological environment under field conditions of Sakar agro-ecological region.

In ecological environment and without using of pesticides and mineral fertilizers the vegetative development of the spring naked oats variety "Mina" passes normally. The duration of the vegetation period ranges from 93 to 115 days. For this period the oats grew by an average of $69.7 \mathrm{~cm}$.

Under the ecological conditions of Sakar agro-region average yields of grain are $1292.830 \mathrm{~kg} / \mathrm{ha}$, and the quantity of straw is $1515.500 \mathrm{~kg} / \mathrm{ha}$. The yields of grain of spring naked oat variety "Mina" grown in ecological conditions are lower compared to the average yields of oats in the country for the same period with $452.50 \mathrm{~kg} / \mathrm{ha}$. This difference is not alarming considering the fact that the production of this variety oats is ecological clean and there is market demand for dietetic foods.
\end{abstract}

Keywords: spring naked oat, ecological environment, vegetative development, growth in period of vegetation, productivity, grain, straw, Sakar region.

\section{INTRODUCTION}

The oats is a cereal which is very well known in Bulgaria. Most of grown varieties of oats are spring. Scientists work to diversify the spring varieties and in the direction of creating new varieties of wintering oats [9]. The naked oats is not a new culture and for it should not be talking like a modern form of oats which is product of biotechnology or genetic engineering. The Russian botanist Vavilov writes about the naked oats as a species known from the wild flora and as a species genetically connected with European cultivars of oats [12]. Successful is the selection of varieties of naked oat in many European countries (Finland, Germany, Great Britain, France, Poland, Sweden, Ukraine, Russia, Belarus), as well as in the United States, Canada and Australia [6].

Attention of the researchers and users is drawn from the fact that the naked oats is sought after for food for people and for feed for animals. The content of amino acids, crude protein and fiber are higher than those of the wheat and the other crops [3]. In addition to the improved biochemical properties of the grain of naked forms of oats is it's unpretentious to growing conditions. So with the years this form of oats began to be sought from producers and processors. The first spring naked oat variety Mina is zoned in Bulgaria in 1994. It is selection made by scientists from IPGR "K. Malkov" in Sadovo [1]. Significant are the research in direction of cultivation, productivity and quality of naked oats $[4,5,10]$. With the 


\section{ART'TE

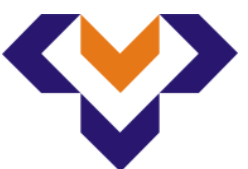 \\ Ipplied Resseirl \\ Journal of the Faculty of Technics and Technologies, Trakia University https://sites.google.com/a/trakia-uni.bg/artte/}

years and due to the established principles of healthy eating, began research work on organically cultivation of cereals and other crops [2].

This research was conducted to investigate the potential of spring naked oat variety "Mina" grown on the principles of organic farming. The influence of soil and climatic indicators on the germination, the vegetative growth, the growth rate in the vegetation period and the productivity are tracked. Reported is the dynamics of growth of the naked oats, as in every 10 days was measured the height of 10 marked for this purpose plants. Morphological analysis of plants was made. Reported are the duration of the periods between phases of growth, the duration of the vegetation period and the yields obtained from grain and straw (kg/ha).

\section{MATERIAL AND METHODS}

The scientific research was conducted under natural field conditions of Sakar agro-ecological region. Studies were carried out in three consecutive years (2009, 2010 and 2011), in properly done preparation, sowing and harvesting of spring oat varieties. The soil type on which was carried out the experiment is a leached cinnamon forest soil (Chromic Luvisols), with acidic reaction and content of humus about $2 \%$. The predecessor, after which was sown oats is peas. According to the requirements for proper farming of the spring oats, after harvesting of predecessor was carried out deep plowing for burying of the residues of peas. The choice of predecessor peas is not accidental and is done to enrich the soil with nitrogen. After the 20 of February at the earliest opportunity to enter in the test area was made disking and cultivating. Sowing was done with sowing norm of $180 \mathrm{~kg} / \mathrm{ha}$. The experiment was carried out according to the method of the blocks in three repetitions and size of the experimental area of $20 \mathrm{~m}^{2}(2 \times 10 \mathrm{~m})$. The harvesting was carried out in technological maturity. The sowing and harvesting were carried out manually. The experiment was carried out in ecological environment and mineral fertilizers and pesticides were not used.

\section{RESULTS AND DISCUSSION}

Most important for the vegetative growth and the productivity of crops grown on the principles of organic farming are the soil type, the proper farming practices and the manifestation of climate indicators. Oats is a culture of temperate climate, which is not pretentious to the soil and can successfully be grown on light sandy and heavier soils. Compared to other cereal crops, it can be grown and on acid soils with reaction of soil in the range of $\mathrm{pH} 5-6$. The oats is a bit pretentious of moisture, but if the treatments are carried out on time and is sown on time, there is a guarantee for normal development and getting real yields.

A curious fact is that from the three types of fertilizers (nitrogen, phosphorus and potassium) the oat reacts more sensitively to nitrogen fertilizers and insignificantly of phosphorus and potassium fertilizers [11]. This suggests that the oat could be grown successfully on the principles of organic farming. From this stems the need in such an environment, the predecessors of oats to be leguminous crops.

Sakar agro-ecological region, in which the experiment was carried out, falls within the continental-Mediterranean area in southeast Bulgaria. The characteristic features of this region are specific microclimate conditioned by the Mediterranean influence and the soil type represented mostly by leached cinnamon forest soils. Compared to many other regions in Bulgaria, this region is remained ecological clean.

According to the report of the municipality of Topolovgrad for development of the municipality in the period 2007-2013 in the region there isn't chemical contaminated land and the whole area is suitable for produce of ecologically clean production [8]. More than twenty years significantly decreased the use of mineral fertilizers and pesticides. This positively affects the

IRTIIE Vol. 4, No. 3, 2016 ISSN 1314-8788 (print), ISSN 1314-8796 (online), doi: 10.15547/artte.2016.03.001 


\section{ARITIE

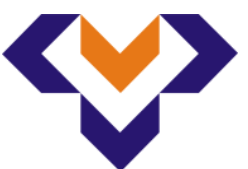

Ipplied Researthes in Technics, Technologies and Bduration

Journal of the Faculty of Technics and Technologies, Trakia University https://sites.google.com/a/trakia-uni.bg/artte/

natural recovery of soils. The agricultural soils in the region occupy $64 \%$ of the total territory of the municipality of Topolovgrad.

The manifestation of the climate indicators is result of the location, topography and mainly from the combination of the two subregions - North Tundzha and Sakar-Dervent Mediterranean sub regions. In this region the winter is mild, with short snowfalls and snowdrifts on the northern slopes, which are retained for a longer time. Spring begins relatively early, in the first half of the month of March and is relatively well secured with moisture. Summer is hot and dry, almost without rain in July and August. The autumn is warmer and quite often drier than spring.

During the years of the experiment the indicators rainfall and temperature vary and have significant deviations from the established norms for the region. For the period from March to July the amount of rainfall in the first and third year is less than the norm for the region, and in the second year is with $78.2 \mathrm{~mm}$ more than the norm (Figure 1). In the months of February and March of the first and second years and the month of April of the third year there is moisture over and above the norm. With insufficient rainfall are the months of April in the first and the second years and the month of May of the second year. With little rainfall are the months of February, March, June and July of the third year. The data on the average temperature indicate vastly warming expressed in a higher average temperature for all three years. The increase compared to the norm for the region is with $0.2-1.2{ }^{\circ} \mathrm{C}$. The average monthly temperature only in April of the third year is much lower than the norm for the region. In all other months the temperature is close to the norm for the region and well above it.

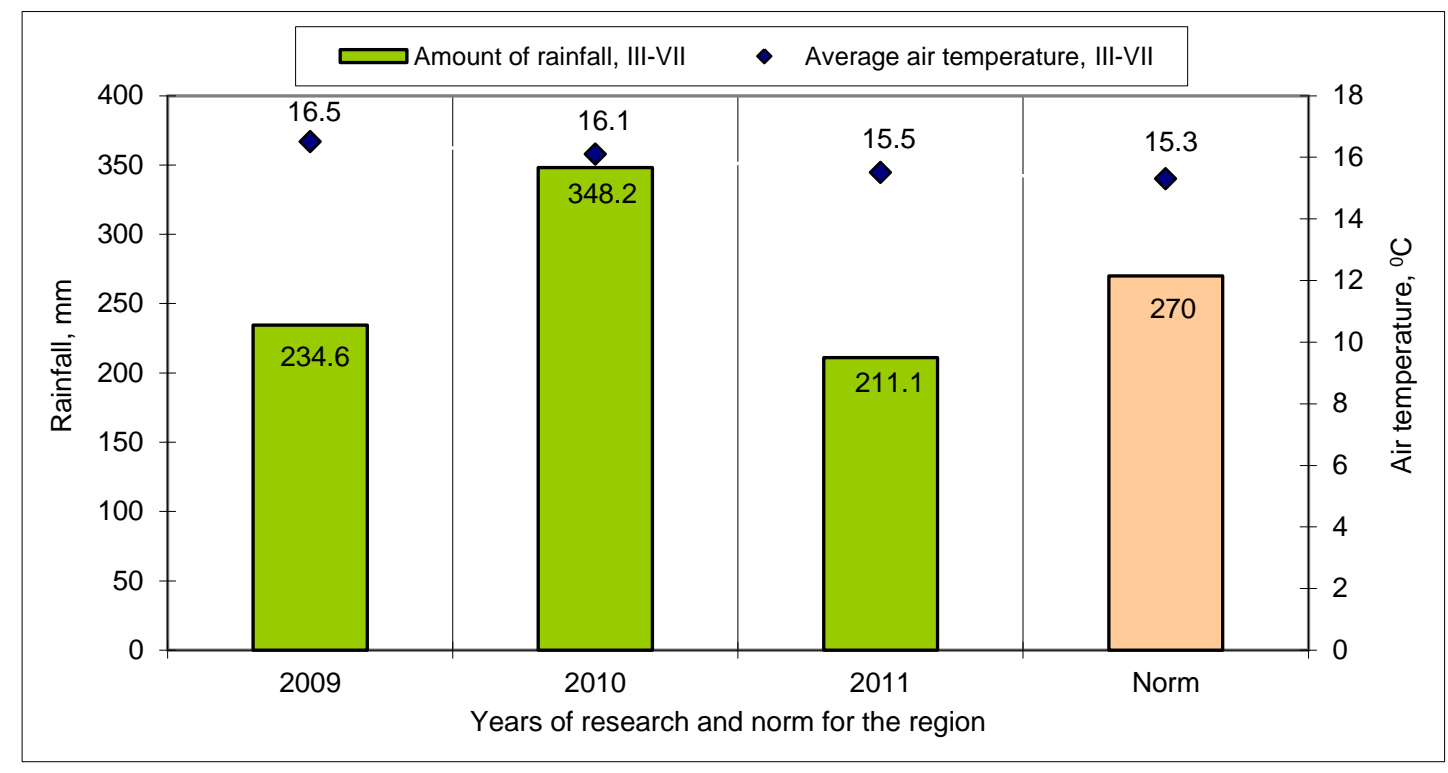

Figure 1. Amount of rainfall and average air temperature during the period III-VII month in the years of research (2009-2011) and norm for the region

In these conditions the sowing in the second and the third years was carried out on time. In the first year because of over-moisture and difficulty of mechanized equipment to enter the field and to prepare the area, sowing was carried out later. The oats germinates on the $13-$ 16 day after sowing. The phases of growth are with different duration. Shortest are the periods between phases of growth in the early stages of development - between "Emergence application"/“Third leaf" - "Third leaf"/“Tillering", about 6 - 8 days. Longest are the periods "Third leaf"/“Tillering" - "Tillering"/“First node" and "Tillering"/“First node" - "First node"/“Inflorescence emergence last spikelet visible" - about 18 - 19 days.

IRTIIE Vol. 4, No. 3, 2016 ISSN 1314-8788 (print), ISSN 1314-8796 (online), doi: 10.15547/artte.2016.03.001 
Table 1. Dates of sowing and germination, duration of the growing season and growth for the growing season

\begin{tabular}{|c|c|c|c|c|c|}
\hline Year & $\begin{array}{c}\text { Date of } \\
\text { sowing }\end{array}$ & $\begin{array}{c}\text { Date of } \\
\text { germination }\end{array}$ & $\begin{array}{c}\text { Germinates } \\
\text { on... }\end{array}$ & $\begin{array}{c}\text { Duration of the } \\
\text { growing season, } \\
\text { days }\end{array}$ & $\begin{array}{c}\text { Growth for the } \\
\text { growing } \\
\text { season, cm }\end{array}$ \\
\hline 2009 & 22. III & 4. IV & 13 day & 93 & 69.9 \\
\hline 2010 & 3. III & $16 . I I I$ & 13 day & 108 & 74.2 \\
\hline 2011 & 1. III & $17 . I I I$ & 16 day & 115 & 64.9 \\
\hline
\end{tabular}

The duration of the growing season of this variety of oats varies from 93 to 115 days. Here the climatic indicators have decisive role. Relatively shorter is the growing season in the first year. It is due to the less quantity of water during the months of April, May and June and higher temperatures during the months of May, June and July. In this case, the later date of sowing has no effect, the oats germinates on time and the vegetative developing is normally. The longest growing season is explained by the delay in germination, which is a consequence of low water availability during the months of February, March, June and July and lower temperatures in April. The duration of the growing season varies in not large borders, but no observed effect on the growth of naked oats for vegetation period (Table 1). Naked oats is the highest in the second year, when it reached $74.2 \mathrm{~cm}$ (Figure 2). Relatively least it grew during the third year. The difference of $9.3 \mathrm{~cm}$ is not large and could not affect the development of the generative organs, if weather conditions do not prevent this.

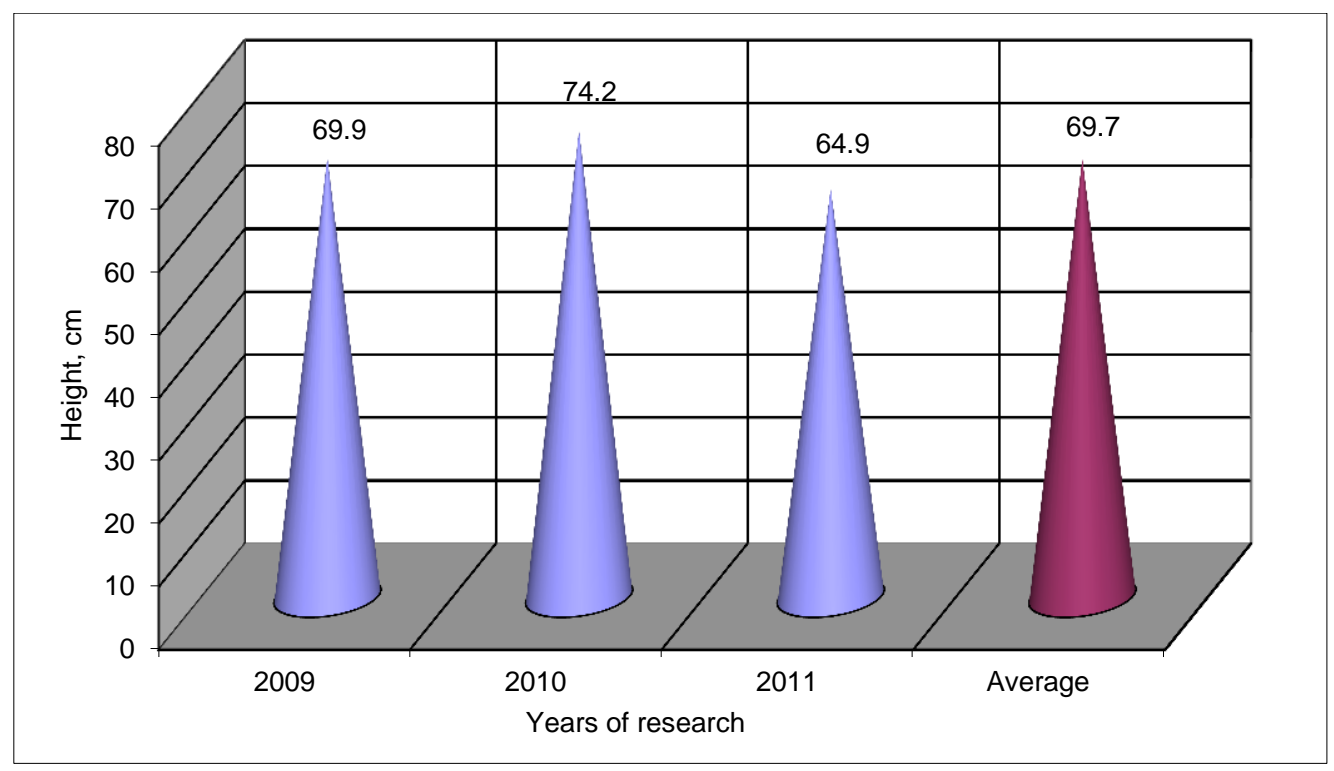

Figure 2.

Growth for the vegetation period in the years of research and average for the period

The morphological features of naked oats variety "Mina" describe it as appearance and are important for its economic qualities. The root system is fibrous, well developed with many primary and secondary roots. One third of the roots penetrate deeper, have a very good absorbability and deliver to the plant water from the lower layers. The stem of this variety of oats is round, smooth and hollow, and stands firmly upright (Figure 3). The bending down is not inherent for the stem. Panicle is located one-sided as its nodes are located on one side. 


\section{AR'TIE Ipplied Researroches in Technics, Technologies and Bduration Journal of the Faculty of Technics and Technologies, Trakia University https://sites.google.com/a/trakia-uni.bg/artte/}

In the terms of Sakar region the length of the panicle is $19.5-22.7 \mathrm{~cm}$ (Table 2). The number of grains in one panicle varies from 28 to 33 . The grain of oat variety "Mina" is naked, light and is not wrapped in typical oats weeds. The weight of the panicle is between $1.42-1.84 \mathrm{~g}$. The weight of 1000 grains is from 20.9 to $23.5 \mathrm{~g}$.
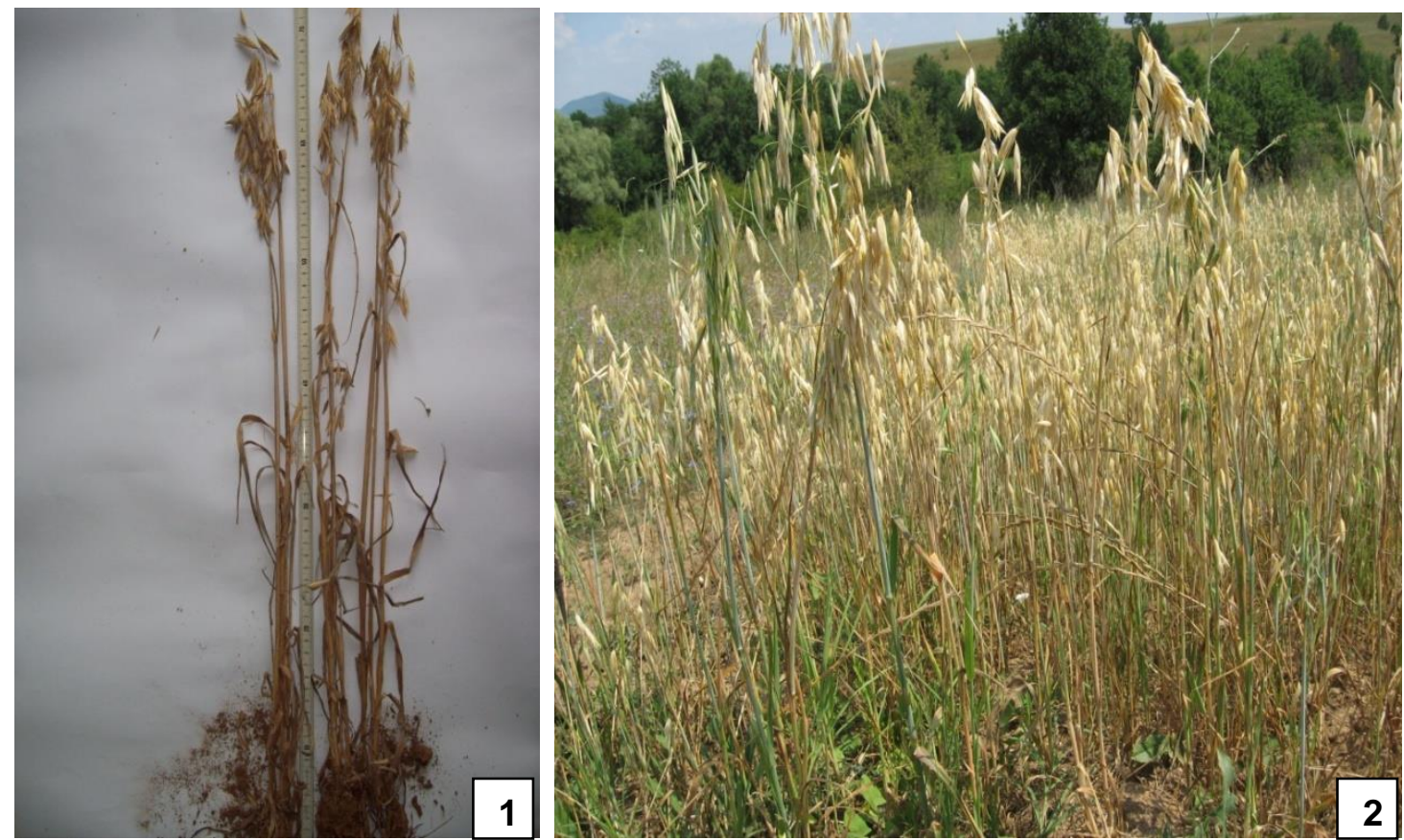

Figure 3.

Spring naked oat variety "Mina"

Table 2. Structural elements of the yield of naked oat variety "Mina" in the years of research and an average for the period

\begin{tabular}{|c|c|c|c|c|}
\hline Year & $\begin{array}{c}\text { Length of panicle, } \\
\mathrm{cm}\end{array}$ & $\begin{array}{c}\text { Number of } \\
\text { grains in 1 } \\
\text { panicle }\end{array}$ & $\begin{array}{c}\text { Weight of the } \\
\text { panicle, g }\end{array}$ & $\begin{array}{c}\text { Weight of } 1000 \\
\text { grains, g }\end{array}$ \\
\hline 2009 & 20,8 & 28 & 1,42 & 20.9 \\
\hline 2010 & 22,7 & 33 & 1,84 & 23.5 \\
\hline 2011 & 19,5 & 30 & 1,61 & 22 \\
\hline $\begin{array}{c}\text { Average } \\
2009-2011\end{array}$ & 21 & 30 & 1,62 & 22.1 \\
\hline
\end{tabular}

The productivity of a culture is influenced by a many factors. When it is grown in condition of organic farming the predominantly influence have the soil moisture and the air temperature. In these circumstances the grain yields of naked oat variety "Mina" are unstable and vary from 1095 to $1475 \mathrm{~kg} / \mathrm{ha}$ (Table 3). The highest yield of grain is obtained in the second year of research when the moisture is the highest. 


\section{IRTITE}

Ipplied Researl reses in Technics, Technologies and Bduration Journal of the Faculty of Technics and Technologies, Trakia University https://sites.google.com/a/trakia-uni.bg/artte/

Table 3. Yields of grain of naked oat variety "Mina" by years and an average for the period of research 2009-2011 for Sakar region and the country

\begin{tabular}{|c|c|c|c|c|c|c|c|c|}
\hline \multirow{2}{*}{ Place } & \multicolumn{5}{|c|}{ Yields by years } & \multicolumn{2}{c|}{ Average } \\
\cline { 2 - 9 } & \multicolumn{2}{|c|}{2009} & \multicolumn{2}{|c|}{2010} & 2011 & $2009-2011$ \\
\cline { 2 - 9 } & $\mathrm{kg} / \mathrm{ha}$ & $\%$ & $\mathrm{~kg} / \mathrm{ha}$ & $\%$ & $\mathrm{~kg} / \mathrm{ha}$ & $\%$ & $\mathrm{~kg} / \mathrm{ha}$ & $\%$ \\
\hline In Bulgaria & 1536 & 100 & 1724 & 100 & 1976 & 100 & 1745 & 100 \\
\hline In Sakar region & 1095 & 71.29 & 1475 & 85.56 & 1309 & 66.24 & 1263 & 72.38 \\
\hline
\end{tabular}

The average yield of grain from naked oat variety "Mina" grown in ecological conditions is $1263 \mathrm{~kg} / \mathrm{ha}$. Obtained yields of oats for the same period in Bulgaria are from 1536 to 1976 $\mathrm{kg} / \mathrm{ha}$. They are higher on average by $27.62 \%$ of those obtained in Sakar region (Figure 4).

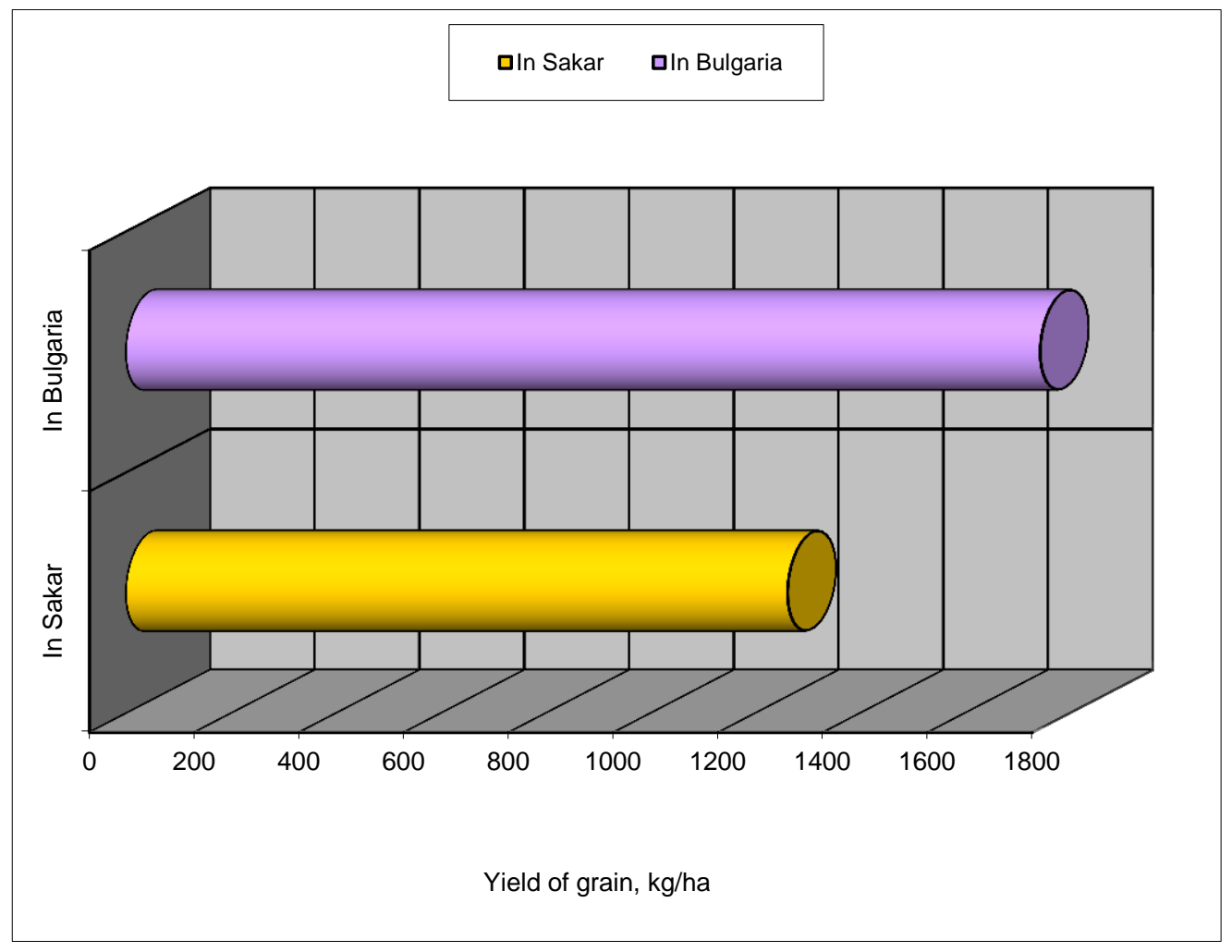

Figure 4.

Average yields of grain in Sakar region and in the country for the period 2009-2011

The straw from cereals is a waste product and usually with the main tillage of soil is buried. Oat straw, however, is a valuable food product that is not reasonably being buried, but it's good to be used to feed the animals. Except that oat straw has a good nutritional value, it has medicinal properties and is used in folk medicine [7]. In cases where oats is grown in ecological conditions, oat straw has better indices and increased demand. The yield of straw in the years of research ranges from 1390 to $1600 \mathrm{~kg} / \mathrm{ha}$ (Fig. 5). It is higher than the yield of grain an average with $252.5 \mathrm{~kg} / \mathrm{ha}$. 


\section{ARTITIE}

Ipplied Researroches in Technics, Technologies and Bduration Journal of the Faculty of Technics and Technologies, Trakia University https://sites.google.com/a/trakia-uni.bg/artte/

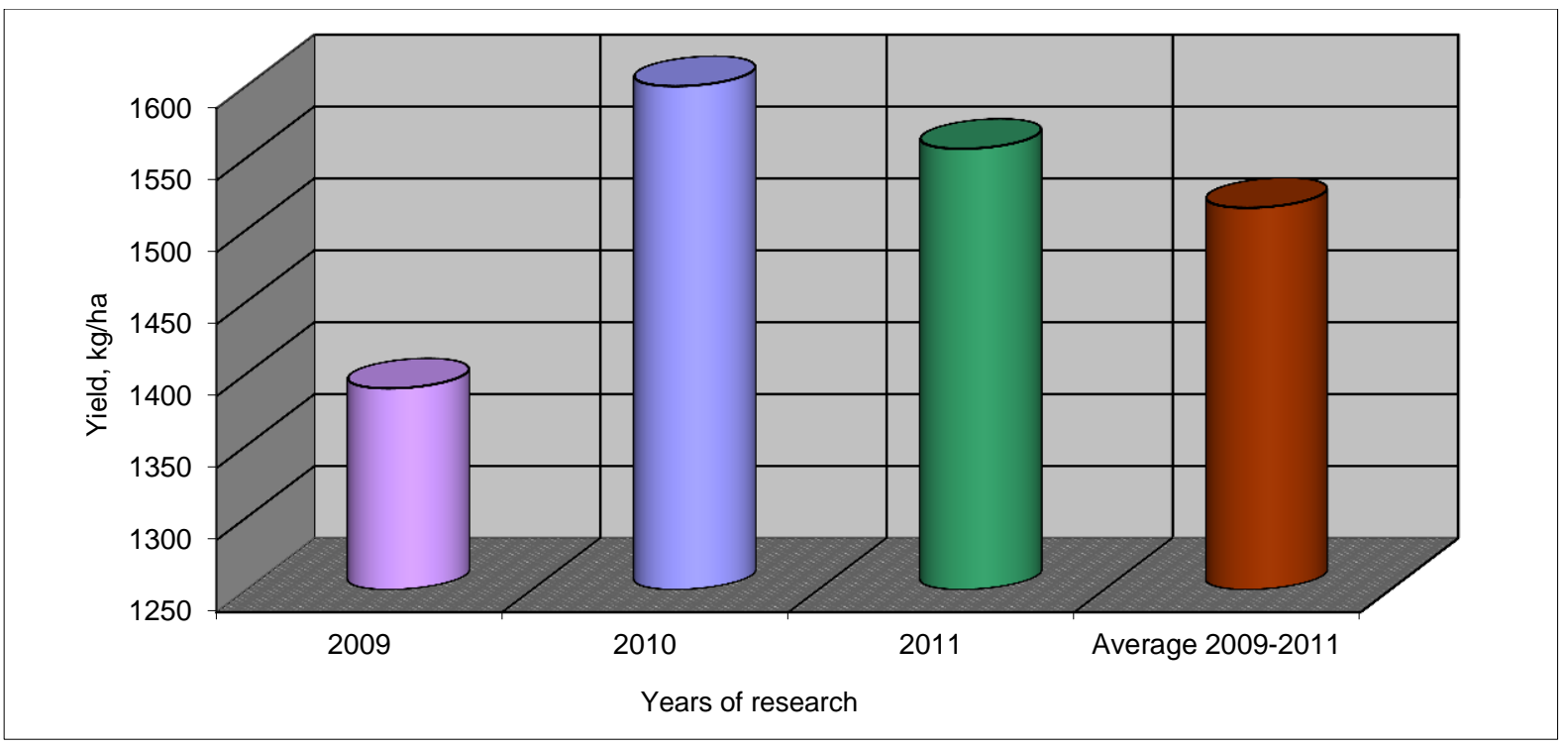

Figure 5. The yields of straw on years and an average for the period of research

\section{CONCLUSIONS}

From the three-year research on the opportunities for growing of spring naked oat variety "Mina" in ecological environment under the conditions of Sakar agro-ecological region can make the following conclusions:

1. When the soil preparation and sowing are carried out on time, the spring naked oats variety "Mina" grown in ecological environment is developing normally.

2. The climate indicators in combination with the soil type are the most important factors from which the vegetative growth and productivity of spring naked oat variety "Mina" depend.

3. The length of growing season on this variety of oats is 93 to 115 days. During this time it grows to $64.9-74.2 \mathrm{~cm}$.

4. In conditions of Sakar agro-ecological region the length of the panicle reaches $22.7 \mathrm{~cm}$, the number of grains in a panicle is up to 33 and the weight of 1000 grains is maximum $23.5 \mathrm{~g}$.

5. The yields of grain are in the range of 1095 to $1475 \mathrm{~kg} / \mathrm{ha}$, and of the straw from 1390 to $1600 \mathrm{~kg} / \mathrm{ha}$.

6. The yield of grain in ecological conditions of Sakar region is lower with $27.62 \%$ than in Bulgaria for the same period.

\section{REFERENCES}

[1] Antonova N., Stancheva J., Dobrev D., Karadjova J. (1995). Spring naked oats variety Mina. Jubilee scientific conference "90 years IASS Obraztsov chiflik, Ruse" Scientific works, Vol. I, pp. 51-55. (Bg).

[2] Bojanova V., Detchev D. (2009). Problems and prospects associated with the cultivation of cereal species organically. International Science conference, June 4-5, 2009, Stara Zagora, Bulgaria. "Economics and Society development on the Base of Knowledge" Volume I, 322. Agricultural science. Plant studies. (Bg). 


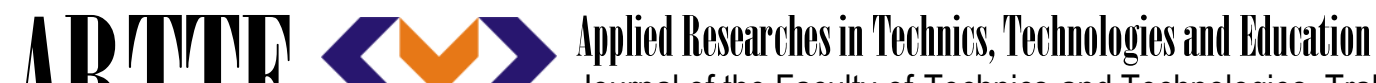 Journal of the Faculty of Technics and Technologies, Trakia University https://sites.google.com/a/trakia-uni.bg/artte/}

[3] Bunyak O. I. (2012). Characteristics of naked varieties of oats (A. sativa subsp. nudisativa) in terms of Nosivskoi SDS/ O.I. Bunyak // Selection and seed. Interdepartmental thematic scientific collection. Vol. 102, p. 169-177. (Ukr).

[4] Burrows J., Moudrý jr. J., Štěrba Z., Bárta J. (2003). Comparison of yield and panicle productivity between hulled (Avena sativa L.) and naked (A. nuda L.) oats. Biuletyn Institutu Hodowli i Aklimatyzacji rostlin, 229:61-64.

[5] Burrows V. D., Molnar S. J, Tinkler N. A., Marder T., Butler G., Lybaert A. (2001). Groat yield of naked and covered oat. Canadian Journal of Plant Science 81:727-729.

[6] Food and Agriculture Organization of the United Nations. Faostat. [Online]. Available: http://faostat3.fao.org/faostat-gateway/go/to/download/Q/QC/E.

[7] http://nanocom-bg.com.

[8] http://www.strategy.bg/StrategicDocuments/View.aspx?lang=bg-BG\&ld.

[9] Savova T., Georgieva T., Vulcheva D., Dimitrova-Doneva M. (2012). Productive capacities of varieties and candidate varieties of oats. Agrarian Sciences, IV, issue 11, pp. 189-195.

[10] Sterba Z., Moudry J. (2001). Yield formation and quality of naked oats (Avena nuda L.). 37th Croatian symposium on agriculture, 262.

[11] Terziev G., Yancheva H., et al. (2006). Plant-growing. Academic edition of AU Plovdiv, 54-64. (Bg).

[12] Vavilov N. I. (1926). Centres of origin of cultivated plants. General biology. (Ru). 